Chapter 8

\title{
Carbon Sequestration in Central European Forest Ecosystems
}

\author{
Robert Jandl and Andreas Schindlbacher
}

Additional information is available at the end of the chapter

http://dx.doi.org/10.5772/57264

\section{Introduction}

The forests of Central Europe play an important role in the retention of atmospheric carbon dioxide. Carbon sequestration is rarely the main objective of forest management and is often an underappreciated by-effect of practical forest management, whereas timber production and protection against natural hazards in mountain regions are the main forest functions. Climate change is expected to alter practical forest management profoundly, by causing changes in productivity in two directions: some regions will be increasingly affected by prolonged drought periods and the growth rate of forests is expected to decline; in mountain regions the growth rate of forests will often increase because climate change will manifest itself by the prolongation of the growing season. Many forests will be affected by an increasing pressure from pests and pathogens, both due to the expansion of the natural habitat, and due to the inadvertent introduction of pathogens in an increasingly globalized market. In the long run climate change will have implications for the tree species distribution. The presently successful Norway spruce will be found in a smaller area because parts of the present habitat will not fulfill the site requirements of this tree species in the future. Such tendencies have far-reaching consequences for the timber industry, so concepts for adaptive forest management need to be formulated. Besides increasing efforts for monitoring forest conditions, development of the opportunities offered by the genetic variability of tree species is an example of pro-active planning. In order to base recommendations for adaptive forest management on a sound basis, climate manipulation experiments are conducted. A network of such experiments enables researchers to make educated guesses on the expected climate change impact on forests. Nevertheless, due to manifold uncertainties with respect to the extent of climate change, its regional realization, the future expectations of society towards forest ecosystems and other imponderabilities, the predictions remain uncertain. 


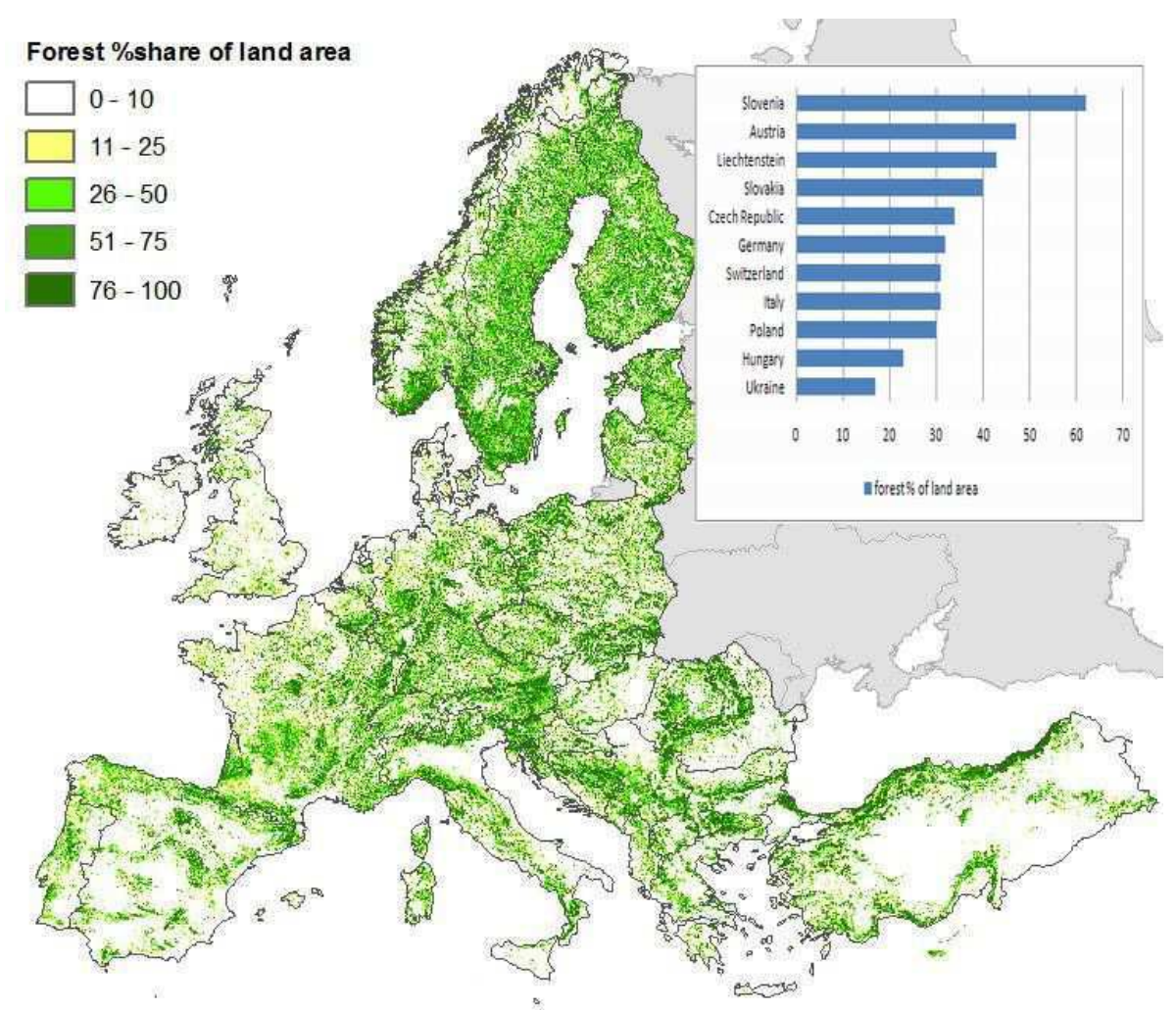

Figure 1. Forest cover of Europe with share of forest in the total land area in Central Europe (inset). European forest cover map provided by the European Forest Institute [2-4].

\section{Spatial extent of forests in Central Europe with emphasis on mountain forests}

Europe has a total forest area of more than 1 billion $\left(10^{9}\right)$ hectares and has a an average forest cover of $\approx 45 \%$ (Figure 1 ). Forests are unevenly distributed. Densely forested areas are in the Nordic countries and in high elevation ecosystems. Central Europe, here comprising Austria, Czech Republic, Germany, Hungary, Italy, Poland, Slovakia, Slovenia and Ukraine, has a total forest area of more than 52 million $\left(10^{6}\right)$ ha with an average forest cover of $35 \%$. This figure is close to the global average of a forest cover of $31 \%$ [1]. The regional distribution of forests is determined by the human population density, the land management options, and by physio-geographic constraints. In low-elevation regions agriculture and settlements are often dominant land covers, whereas in mountainous areas the share of forests increases. A part of the land at high elevation is unproductive because it is situated above the timberline (Figure 2). The economic relevance of agriculture is often inversely reflected in the forest cover. Currently, abandonment of agricultural land allows the expansion of forests, both by encroachment of marginal crop- and grassland, and by concerted afforestation programs. 


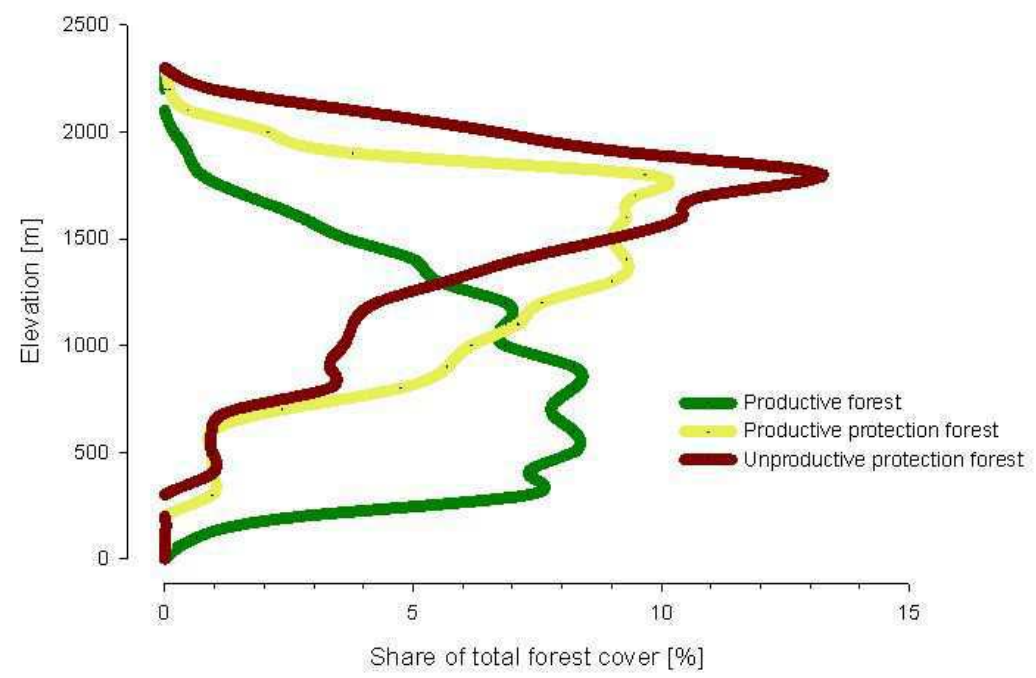

Figure 2. Typical elevational distribution of forests in a mountainous region with productive forests at low elevation and an increasing share of protection forests at high elevation; Data from Austrian National Forest Inventory [5].

The forest cover on managed land increases with altitude and its carbon pools in the aboveground and belowground biomass and in the soil are highly relevant for climate change policies. Although the rate of carbon sequestration in slowly growing forests is low, the maintenance of the carbon pool by minimizing forest disturbances is important. Mountain forests are often well adapted to harsh climate conditions and are, despite natural disturbances, stable elements of mountain ranges. However, when the reporting modalities for national greenhouse gas budgets are confined to actively managed ecosystems, as under the Kyoto Reporting Rules, the role of many mountain forests is not fully recognized because they are not managed [6, 7].

Natural forest dynamics are driven particularly by climate factors. Under increasingly favorable climate conditions, the major constraints to forest growth at high altitudes, such as short growing seasons and low temperatures, are being alleviated and the timberline is moving upwards. Superimposed on this tendency are changes in land use practices. In Central Europe the active management of mountain pastures is declining for economic reasons, and forests are expanding into these areas $[8,9]$. The main economic reason is that high-altitude cattle grazing is no longer competitive in an increasingly globalized market for agricultural produce; the political reasons are strong public preferences towards ecosystem conservation in mountain ranges at the cost of practical forestry.

Climate change has positive outcomes for some tree species but may lead to reduction of habitat size or even extinction of other trees [10,11]. Such changes have far-reaching consequences such as the alteration of the provision of drinking water from forested mountain watersheds, alteration of the protective function of for forests against natural hazards, and the biological and structural diversity of landscape. The impact of these changes 
is felt in timber production, but also by the local community that is making a living in mountain areas. While rising temperatures benefit the growth of trees, they also facilitate the more rapid growth and expansion of populations of pests and disease-causing organisms $[12,13]$. This pressure is further exacerbated by the rapid distribution of such organisms through global market streams. Together, these global change processes increase the pressure on mountain forests. In regions of extensive forestry, outbreaks of pests and diseases have caused major damage to mountain forests: for instance, millions of hectares of lodgepole pine (Pinus contorta) in the Canadian Rocky Mountains have been lost to mountain pine beetles (Dendroctonus ponderosae), releasing considerable quantities of carbon and putting forest-dependent communities at risk. An often observed phenomenon is bark beetle infestation in the wake of storm damages that has been observed in Central and Northern Europe [14-16]. In regions of intensive forestry, monitoring of pest and pathogen densities is becoming ever more essential and widespread, and silvicultural costs will increase due to the need for international and national alerting and monitoring programs to combat insect and disease outbreaks at an early stage.

In regions where precipitation is increasing, weather conditions will contribute to reduced fire frequency but, at the same time, increased tree cover promotes fire. Regions that are becoming drier and often warmer are likely to have a higher risk of wildfires [17]. Both of these trends require better understanding of the processes involved, and more effective monitoring and rapid response in the case of emerging problems. Nevertheless, many fires are started intentionally or accidentally by people, so that climate change is only one of many factors to be considered. While changes in average temperature and precipitation lead to certain negative impacts, changes likely to result from increased numbers of extreme events are at least as critical. Examples include windstorms and heavy rain and snowfall. Such events will endanger the stability of mountain forests and hence the provision of their ecosystem services.

The role of mountain forests in the mitigation of climate change is rather passive. Their loss would release large amounts of $\mathrm{CO}_{2}$ into the atmosphere. Their protection, conservation and management are therefore important, so some governments are promoting the establishment of forests in mountain areas as part of their climate change policies or to benefit from carbon credits, sometimes through the United Nations Collaborative Program on Reducing Emissions from Deforestation and Forest Degradation in Developing Countries (REDD). Active mitigation - the absorption of $\mathrm{CO}_{2}$ in biomass and soils - is slow because the growth of trees and chemical processes at high altitudes is slow. A second field of mitigation is the substitution of fossil fuels with renewable forms of energy. In this context, mountain forests play a modest role since trees generally grow slowly. Nevertheless, some species, which are not of great value for timber, can be regarded as reliable sources of biofuel - as can parts of large trees, such as smaller branches, that are not valuable as timber. Given growing energy demands, all efforts to increase the efficient use of energy are important, so that key needs are to ensure that fuelwood is used more efficiently and that, wherever possible, other renewable energy sources are used.

Adaptation to climate change may be reactive or planned. Reactive adaptation includes actions such as changes in harvesting levels and schedules, the removal of downed trees after storms and the use of the resulting wood, and the development of socioeconomic support programs for communities experiencing negative impacts. Planned adaptation 
implies the redefinition of forestry goals and practices, taking into consideration the risks and uncertainties associated with climate change [18]. Management plans will have to include uncertainty and the increased probability of extreme events, and be regularly updated. Farmers, communities and forestry companies and agencies alike need to identify plant species or provenances which will grow well and ensure stable and productive forests in the climates of the later decades of the $21^{\text {st }}$ century, contribute to local livelihoods and, in particular, ensure forest cover in areas with an increased risk of erosion, landslides or other natural hazards. For communities, adaptation may include better governance of forest resources, capacity building to monitor and cope with extreme events, increased use of agroforestry practices, and diversification of income sources. At national and global levels, key actions may include the development and implementation of monitoring and reporting systems and tools for vulnerability assessments and adaptation planning, as well as increasing the flexibility of organizational cultures, structures, and forest-related policies before crises arise [19].

\section{The carbon pools in forests}

The United Nations Framework Convention on Climate Change calls for its Parties to develop, periodically update and report national inventories of anthropogenic emissions by sources and removals by sinks of all greenhouse gases not controlled by the Montreal Protocol, using comparable methodologies. Estimating and reporting anthropogenic emissions and removals to the international community are important to develop policies to control the emissions and removals of greenhouse gases (GHG), which are believed to be the principle causes of the recent anthropogenic climate change. Each country needs to submit annual reports on emissions and removals of GHGs for all relevant sectors of the economy. The estimation and reporting must be complete, accurate, transparent, consistent over time and comparable between countries $[7,20]$. For forest ecosystems, five compartments are reported:

- aboveground biomass

- belowground biomass

- dead wood

- litter layer

- soil organic matter

Among the principles of estimating changes in the carbon pool size is that the demonstration should be "scientifically sound". However, the accounting rules are not explicit about the strategy of dealing with uncertainty. A common approach is the calculation of a "central estimate" (mean value) and the uncertainty around it (standard deviation). Another approach is to assess the margins of the uncertainty range [21].

The reporting is done differently in individual countries. The Good Practice Guidance identifies key categories that have a significant influence on a country's greenhouse gas inventory. When land use (agriculture, forestry, other land use 'AFOLU') is a key category countries use methods of higher complexity and with higher data demands (tier levels). Tier 1, the simplest version, applies to countries in which forests and the biomass carbon 
pool) is not a key category and where no country-specific activity data are available. Tier 2 applies where forests and biomass carbon form a key category and where country-specific estimates of activity data (e.g. forest inventories) are available. Tier 3 applies where the "forests remaining forests" and biomass carbon form a key category. It requires detailed national forest inventory data supplemented by dynamic models or allometric equations calibrated to national circumstances that allow for direct calculation of biomass increment $[7,22]$.

The most reliable data are available for the aboveground biomass due to the highly developed forest inventory systems in Europe [23]. The rotation period of managed forests is variable between ecosystem types, yet well recorded. Therefore, the estimates of the longevity of carbon residing in the aboveground biomass are well supported by data.

The information on the belowground biomass of forest ecosystems is much scarcer for several reasons. The root biomass is economically irrelevant and the required sampling effort is high. There is substantial uncertainty about the representative rooting depth of trees and the arbitrarily chosen reporting depth of 30 to $50 \mathrm{~cm}$ may greatly underestimate total belowground biomass. The longevity of the root biomass varies in a wide range. Fine roots turn over quickly, whereas the decomposition of root stumps requires many decades and is affected by numerous site factors [24-26]. Often the belowground biomass is estimated by means of generic equations [27]. Despite the challenges in quantifying the standing stock of roots and their turnover rate, it is of paramount interest to improve this understanding. Roots are important sources of soil carbon. It has even been argued that the intricate network of roots and fungi is the most important source of slowly turning over soil carbon in boreal forests. Hence their role for long-term soil carbon sequestration is large [28].

Dead organic matter, i.e., the residues of fallen logs and decomposing branches and twigs, is also difficult to quantify. The amount of coarse woody debris left on-site after harvesting operations depends on the local demand for biomass on the industrial market, and on the pursued forest management concept.

Litter layer and soil organic matter are difficult to assess because their carbon pool sizes are spatially heterogeneous. There is no unambiguous evidence for either positive or negative impacts of climate change on soil carbon stocks. There are suggestions for enhancing soil $\mathrm{C}$ stocks at higher atmospheric $\mathrm{CO}_{2}$ concentration and reducing soil $\mathrm{C}$ stocks when temperatures are rising. The factors of climate change affect soil $\mathrm{C}$, with the effect on soils of $\mathrm{CO}_{2}$ being indirect through photosynthesis and the effects of weather factors being both direct and indirect. Climate change affects soil carbon pools by affecting each of the processes in the C-cycle: photosynthetic C-assimilation, litter fall, decomposition, surface erosion, and hydrological transport. Due to the relatively large gross exchange of $\mathrm{CO}_{2}$ between atmosphere and soils and the significant stocks of carbon in soils, relatively small changes in these large but opposing fluxes of $\mathrm{CO}_{2}$ may have significant impact on climate and soil quality. Therefore, managing these fluxes through proper soil management can help mitigate climate change considerably [29-31].

\section{Role of forestry sector in national greenhouse gas budgets}

Greenhouse gases comprise several gases but not all of them are equally relevant in forest ecosystems. The dominant gas with the highest relevance for European forest ecosystems 
is $\mathrm{CO}_{2}$, whereas nitrogen oxides $\left(\right.$ e.g., $\left.\mathrm{N}_{2} \mathrm{O}\right)$ and methane play a smaller role. In Central Europe, forests are mostly sinks of carbon dioxide. ${ }^{1}$ The reasons are the increase in the forest area at the expense of agricultural land and the discrepancy between high growth rates and low harvesting rates in forests. Land-use change is an ongoing process and there have been successful policy incentives for a more efficient use of forests. Forest products are carrying several elements of a knowledge-based bioeconomy of the European Union. Fibers from woody plants are relevant as raw material for industrial processes and the use of wood biomass as a source of energy is being promoted in order to reduce the dependency of the continent from fossil fuels. However, the entire sector plays a rather marginal role in greenhouse gas emissions. Less than $5 \%$ of the total greenhouse gas emissions are compensated by the sector 'land use, land-use change, forestry' (Figure 3). This figure is in reasonable agreement with the estimate of 7 to $12 \%$ of $\mathrm{CO}_{2}$ absorption in terrestrial ecosystems based on modeling results [32]. Nevertheless, the graph shows that forestry is the only sector that is a reliable sink of greenhouse gases. A second observation is that the emissions of greenhouse gases are declining because of the economic crisis in 2007. On a global scale no decline in greenhouse gas emissions was observed. On the contrary, due to the rapid development in previously less developed regions in Asia the emissions remained at high levels and the rate of annual emissions is even accelerating [33]. The top four emitters in 2011 covered $62 \%$ of the global emissions: China (28\%), United States (16\%), EU27 (11\%), and India (7\%). Among them, emissions have strongly increased in 2010/11 in China and India, and slightly decreased in the United States and Europe [34, 35].

Only recently was the carbon-dioxide sink strength of forests on a global level evaluated as strong and persistent, although the absolute size of the sink and the major contributing regions remained unclear $[36,37]$. However, climate change includes elements that in the long run are prone to lead to carbon losses from terrestrial ecosystems [38]. However, currently European forests are a sink of $\mathrm{CO}_{2}$. For the 25 member states of the European Union (EU-25) and the timespan 1990 to 2005, the long-term carbon forest sink was estimated to be $75 \pm 20 \mathrm{gC} / \mathrm{m}^{2} /$ year, with approximately a third of the carbon going into the forest soil and two thirds ending up in unharvested tree biomass [39]. For European forests there are already some indications that the sink strength of forests will not continue at the present rate. The rate of stem growth is decreasing and thus the sink is declining after decades of increase. In addition, the increasing demand for agricultural land and for the establishment of settlements and infrastructures leads to deforestation. The subsequent vegetation cover after forest clearance has a lower carbon density. And finally, an increasing rate of ecosystem disturbances due to extreme climate events and due to biotic hazards exerted by pests and pathogens are leading to the loss of forest stands [40].

The narrative for the greenhouse-gas sink in the forestry sector is given by the example of the Austrian National Inventory Report of the year 2012 [42].

In 2010 Article 3.3 activities, i.e. afforestation, reforestation and deforestation activities, were a net sink in Austria: Net $\mathrm{CO}_{2}$ removals amounted to $1259 \mathrm{Gg} \mathrm{CO}_{2}$. Removals from afforestation/reforestation amounted to $2621 \mathrm{Gg} \mathrm{CO}_{2}$. About 2/3 of these gains were caused by the $C$ stock increases in soil and litter, $1 / 3$ was due to

\footnotetext{
${ }^{1}$ National Inventory Reports: http://unfccc.int/national_reports/annex_i_ghg_inventories/national_inventories_ submissions/items/7383.php; accessed Aug 18, 2013
} 


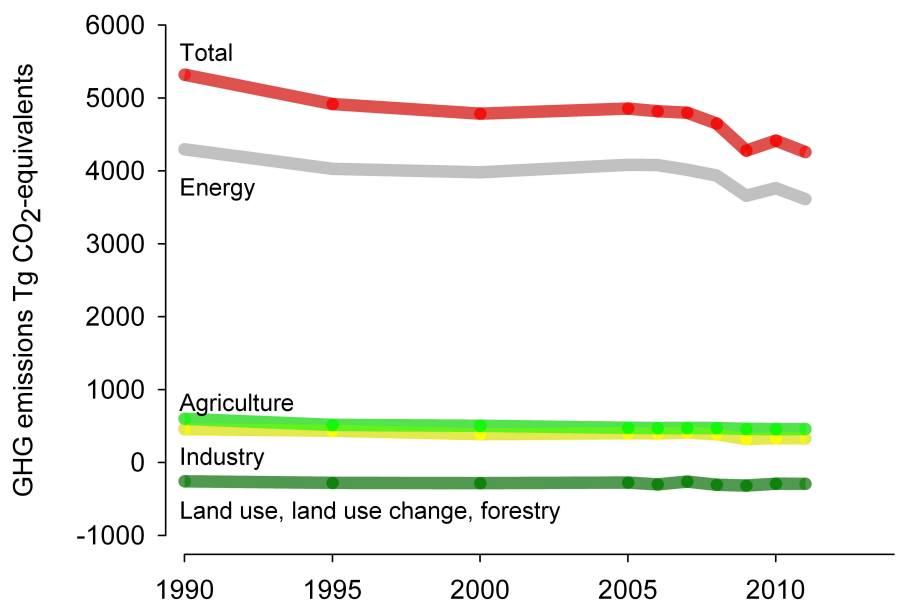

Figure 3. Overview of EU-27 GHG emissions in the main source and sink categories 1990 to 2011 in $\mathrm{CO}_{2}$ - equivalents (Tg); [41]

biomass growth in the afforestation/reforestation areas. Approximately 37\% of these removals occurred in afforestation/reforestation areas from grassland, $18 \%$ in afforestation/reforestation areas from 'other land', 17\% from settlement, $16 \%$ from cropland and $12 \%$ from wetlands. In the same year, emissions from deforestation amounted to $1362 \mathrm{Gg} \mathrm{CO}_{2}$. A bit more than $2 / 3$ were due to $\mathrm{C}$ stock losses in litter and soil, and $1 / 3$ due to biomass losses in the deforestation areas. Approximately $30 \%$ of these losses occurred in deforestation areas to grassland, $28 \%$ to settlement, $25 \%$ to other land and the rest in deforestation areas to cropland and wetlands.

The net carbon stock changes of forests vary considerably between single years. The annual growth rate and the annual harvest rate can differ significantly year by year due to variations in weather conditions, the market situation for timber, and the intensity of ecosystem disturbances. In the example of Austria, forests have been a strong and reliable $\mathrm{CO}_{2}$ sink for many years. The reason is that harvesting rates were far below the annual increment. A successful political campaign for the utilization of timber resources and high timber prices gave sufficient incentives for increased harvesting rates. The positive effect on the timber market had the immediate by-effect that the carbon sink strength of forests was reduced. In addition, a series of storm damages of forests unintentionally led to high harvest and salvaging rates. For a single year these disturbances even caused forests to be a source of $\mathrm{CO}_{2}$ rather than a sink. Figure 4 gives a clear indication that the main inter-annual volatility of the GHG-budget in forests is determined by forests remaining forests. Land-use change, e.g., the conversion of cropland to forest and grassland, to forest plays a marginal role.

\section{Effect of land use change on carbon sequestration}

The establishment of the agricultural societies starting 60000 years ago has shaped the European landscape. Forests were cleared to enable the establishment of cropland and 


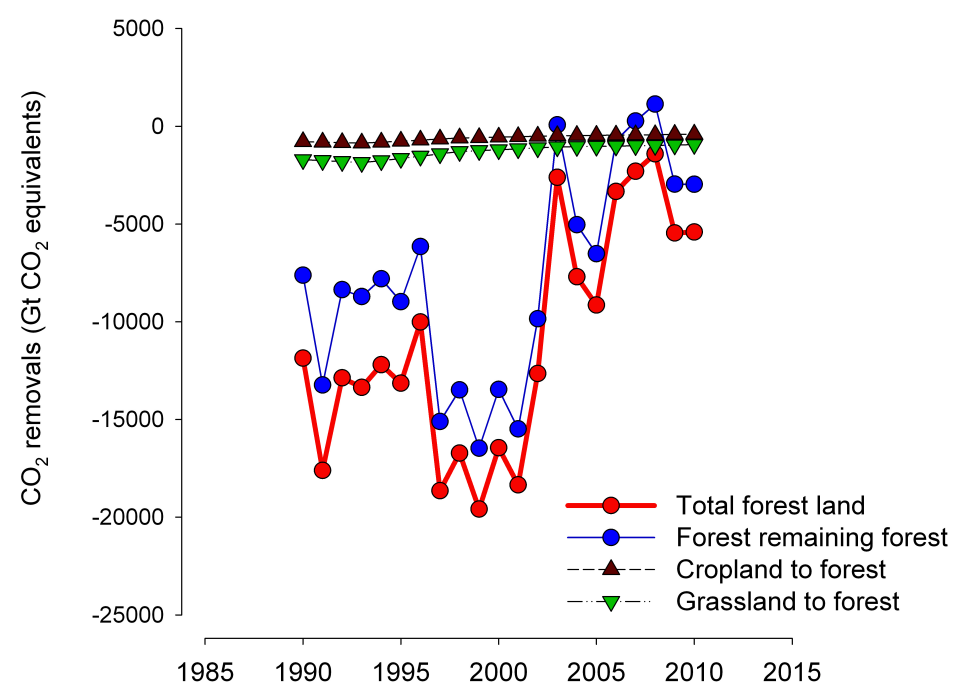

Figure 4. Removals and emissions of carbon dioxide in the forests of Austria according to the IPCC category 'Forest remaining forest', and forest land conversions from 1990 to 2010 (GT) $\mathrm{CO}_{2}$ equivalents).

pastures. Forests were used both for the wood and non-wood products [43]. Extensive European deforestation started around 1000 BC [44].

Mountain regions play a peculiar role. Their settlements are exposed to natural hazards such as flooding and avalanches. Forests can mitigate these dangers because they affect the hydrology and the ability to stabilize a snow cover. A prerequisite for the protective function is the sustainable maintenance of an optimal stand structure [45, 46]. With awareness of the primary relevance of permanent forest cover in alpine regions, forest management schemes were greatly restricted. Already in the $16^{\text {th }}$ century the exploitation of mountain forests in the Alps was constrained by Forest Acts in order to avoid natural disasters and the rapid degradation of mountain regions. However, mountain regions were often poverty traps because the low productivity of the land impaired economic development and the politcal representation was low. In politically labile times such as in the aftermath of the Napoleonic Wars the legal status of the forests in parts of the Alps was unclear. Quickly, overexploitation of the forests took place as a manifestation of the "tragedy of the commons" [47]. Often farmers were in economically desperate situations and means of increasing the productivity of agricultural lands such as mineral fertilizers were not yet available. The remedy was the deforestation of land at high altitudes to provide pasture land for an increasing number of livestock. The dire consequences followed within a short period of time. As early as 1852 a stringent Forest Act ("Reichsforstgesetz") was implemented and administrative and technical bodies for torrent control were established. Incontestable proof of the relevance of a dense and sustainable forest cover was given by the classic 'Sperbelgraben/Rappengraben' hydrological experiment in Switzerland [30,48]. Even the establishment of academic forestry curricula in Central Europe was a direct consequence of a series of natural disasters. 

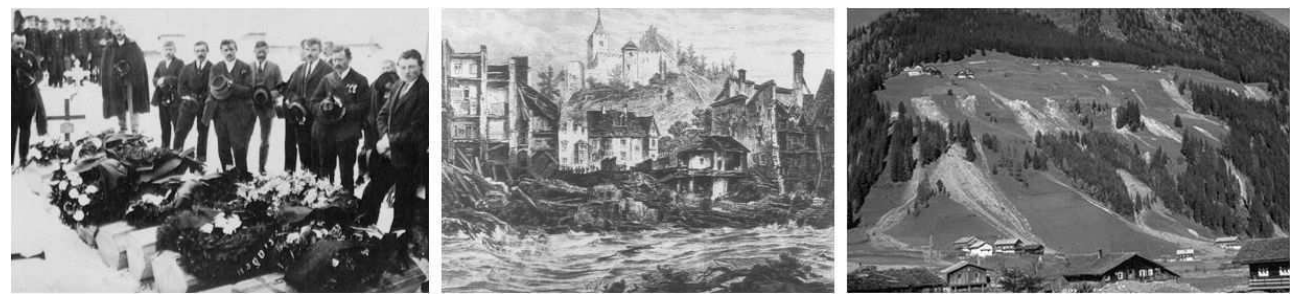

Figure 5. The poor condition of mountain forests led to numerous natural disasters. Mourning the death after avalanches in Villgraten, Eastern Tyrol in 1931 (left), catastrophic flooding in the city of Sterzing, Southern Tyrol (center), and soil erosion in Eastern Tyrol (right); [50].

In recent history, the forest area in mountain regions was reduced several times. The Oetztal in the western Austrian province of Tyrol is such an example. Between 1774 and 1880 the forest area was reduced by more than $50 \%$. The political unrest during the Napoleonic Wars led to little control of land use. The precarious income situation for agriculture in the valleys was based on potato, beets, and cabbage as main crops. The land was used at its maximum carrying capacity [49]. The extension of agricultural land in high altitudes offered one of the few options to increase the income in agriculture. The immediate consequence of this overuse of mountain regions and the removal of mountain forests was an increase in the frequency and severity of natural disasters 5. It was even pondered whether permanent settlements in some parts of the Alps should be given up and whether the population should be relocated to safer ground [45].

Today, the reverse process is underway. Mountain areas in the Alps are prospering economically as tourism is growing as a pillar of the economy. They are widely recognized as water towers with an immense impact on the lowlands. In addition, a part of the increase in the Central European forest area is due to the expansion of mountain forests. In particular at high elevation were mountain pastures are abandoned, forests are encroaching on the now unmanaged land [5]. The process has several implications. One is a loss in biodiversity because the forested landscape is becoming more uniform in comparison to the variety of pasture lands with a wide range of management intensities. However, from the perspective of climate mitigation the tendency towards more forests is beneficial because the carbon density in forests is higher than in other types of terrestrial ecosystems [36, 51-53]. It has been concluded that the effect of climate change has an impact on the soil carbon pool size in the longer term. However, the climate signal is much weaker than the effect of land use change and land management [31].

\section{Expected climate change impact on tree species and pests and pathogens}

There is agreement that in many regions of Europe, and even globally, climatic change will manifest itself in terms of little change in the precipitation regime, but in higher temperatures and longer growing seasons. Precise regionally valid climate predictions are still elusive and the uncertainty of the estimates is expected to remain large [54,55]. Even apparently simple phenomena such as the length and frequency of drought periods are difficult to quantify and widely different statements on the expected temporal trend of drought periods are 
presented [56, 57]. However, there is clear evidence that unprecedented rates of tree mortality are happening. Particularly in already dry areas, it is questionable whether forests can re-establish themselves or whether they are regionally going to be replaced by shrublands. Nevertheless, almost all forest types are expected to be affected by drought $[17,58]$. The effects of that for carbon sequestration are dramatic. Currently, forests in Europe are a potent sink for carbon dioxide in the atmosphere. However, under increasing stress, the sink strength will be difficult to maintain $[39,40]$. Outside of Europe there is already widespread evidence of drought events with massive deleterious effects on the carbon storage in forests [59].

Forest fires are recognized as a substantial future risk for Central European forests. Due to active fire suppression, the incidents of forest fires are still rare and are often caused by human negligence rather than being triggered by climatic phenomena. However, this danger has to been kept on the agenda, particularly because the lengthening of the growing seasons will also extend the fire season. Wildfires not only diminish the tree biomass, they also have long-term adverse effects on the soil carbon pool [60,61].

Despite the widespread recognition of drought as a threat to forests, currently the greatest damages in Central European forests are caused by storms and bark beetle attacks. There is some evidence that the frequency and severity of storms is increasing [62]. However, the observed signal needs to be interpreted with high caution. The scientific evidence whether or not the strength of storms is increasing is still insufficiently corroborated, although indications are recorded [63, 64]. Furthermore, the predictability of storms in global climate models is confined to advection events whereas locally severe events can be caused by convective processes that are not fully covered in regionalized climate models. A consequence of devastative storm damages is the attack of the broken stems by bark beetles. Due to constraints in the available work force and the difficult accessibility of storm-damaged sites, dead wood can be left on site for long periods. Especially in the first weeks after the disaster the still moist wood presents an ideal breeding ground for Ips typographus and other bark beetles. Without effective and often expensive counter-measures, the bark beetle effect can spread from the damaged sites (Figure 6). Foresters in Central Europe often have the chance to salvage damaged forest stands, thereby containing the risk of large-scale damages. In parts of the world where forests are unmanaged or only extensively managed bark beetle infestations can reach dramatic sizes, as shown from the example of forests in Western Canada [15].

An emerging threat is the occurrence of introduced pests and pathogens. This phenomenon is not new. Elm disease, the spread of potato weevils (Cylas puncticollis), and the vine fretter (Phylloxera vastatrix) are iconic examples. Globalization aggravates the challenge. In globally transported woody packaging material and in transported organic material such as soils, plants and fruits that are vectors of diseases are inadvertently carried to new ecosystems. A recent example of the introduction of new pests is the infestation of trees in northern Austria with the Asian longhorned beetle (Anoplophora glabripennis) and the longhorned citrus beetle (Anoplophora chinensis) [65, 66]. These species are native to Asia and have been introduced into Europe mainly with packaging wood material and ornamental plants from China or other Asian countries. Under suitable site conditions these endemic species can be persistent and even invade new territories. Favored by climate change the new pests can often use the new habitat as a starting point for a widerrs a poleward shift in the distribution of pests and pathogens by almost $3 \mathrm{~km} /$ year has been observed [12]. 

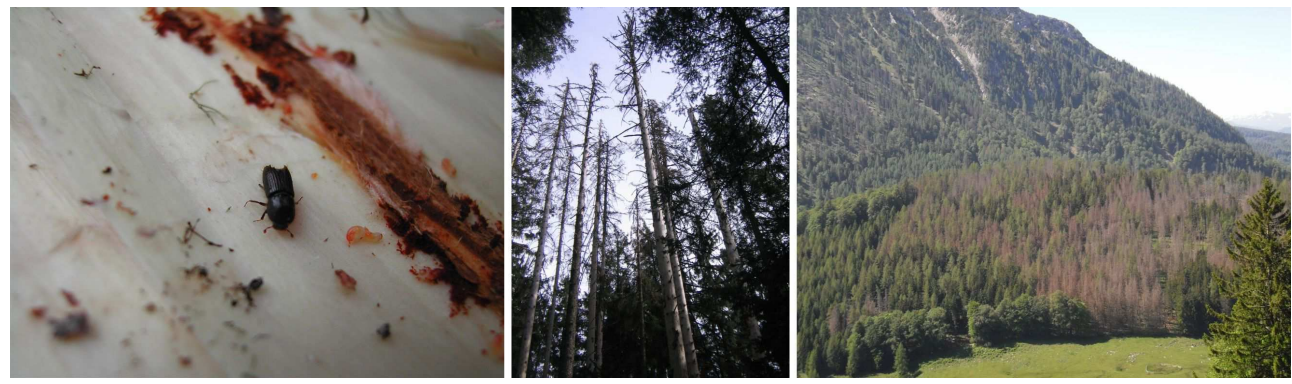

Figure 6. The bark beetle, Ips typographus, is a common pest in secondary spruce forests (left). The infestation extends from single trees to the adjacent previously healthy trees (center), and can ultimately kill the entire forest stand within a few months (right); pictures@: Christian Tomiczek.

From a human perspective, disturbances of forests mostly have a negative connotation. Besides the economic loss, carbon dioxide is also lost from the ecosystem. The slogan 'slow-in/fast-out' has been coined for the quick release of carbon dioxide due to a storm event after decades of carbon accrual in the biomass [67]. However, disturbances are also acknowledged to be a part of the natural ecosystem dynamics [68-71]. Many trees in harsh environments can only germinate and develop because uprooted trees provide site conditions that are far better than in the immediate vicinity of a fallen stem. Moreover, the recent increase in damages in Central Europe can be explained by a combination of climatic factors and forest management strategies. Forests have become more vulnerable: (i) ecologically less stable tree species have been planted for economic reasons, and (ii) the low harvesting rates have led to denser and higher forest stands that are less able to withstand storms [72].

The tree species in Central Europe are currently distributed as shown in Figure 7. The distribution only partly reflects the potential natural vegetation. The proportion of Norway spruce (Picea abies Karst.) has been greatly increased by forest managers because of the high productivity of spruce forests. The instability of secondary spruce forests has been known for more than 100 years. Nevertheless, the economic opportunities of a spruce-based timber industry in the Alps have made the higher production risk acceptable [73].

Predictions on the effect of climate change on the tree species composition are highly uncertain because a complex interaction of species-specific parameters and competitive processes within forest stands needs to be considered. In the past the potential natural tree species distribution has served as a useful reference for a target composition of adapted forests for a given set of site parameters [74]. Under the influence of climate change this reference is losing relevance as an indication of the 'non-analogues future'. The present potential natural vegetation is of little relevance when climate change affects the thermal regime and when nitrogen deposition leads to fundamentally altered soil fertility conditions, thereby creating site conditions that have not been encountered before. Niche models are a useful and transparent tool for creating 'species-distribution maps' [75-77]. These maps show a potential distribution and as such an end-member of a long process of a fundamental change in the vegetation. Niche models yield no information on the temporal course of species migration and do not include the adaptive capacity of species. In addition, they are based on information on the currently realized niche of tree species. The fundamental niche may or may not be substantially larger. Hence, their main purpose is constraining the many 


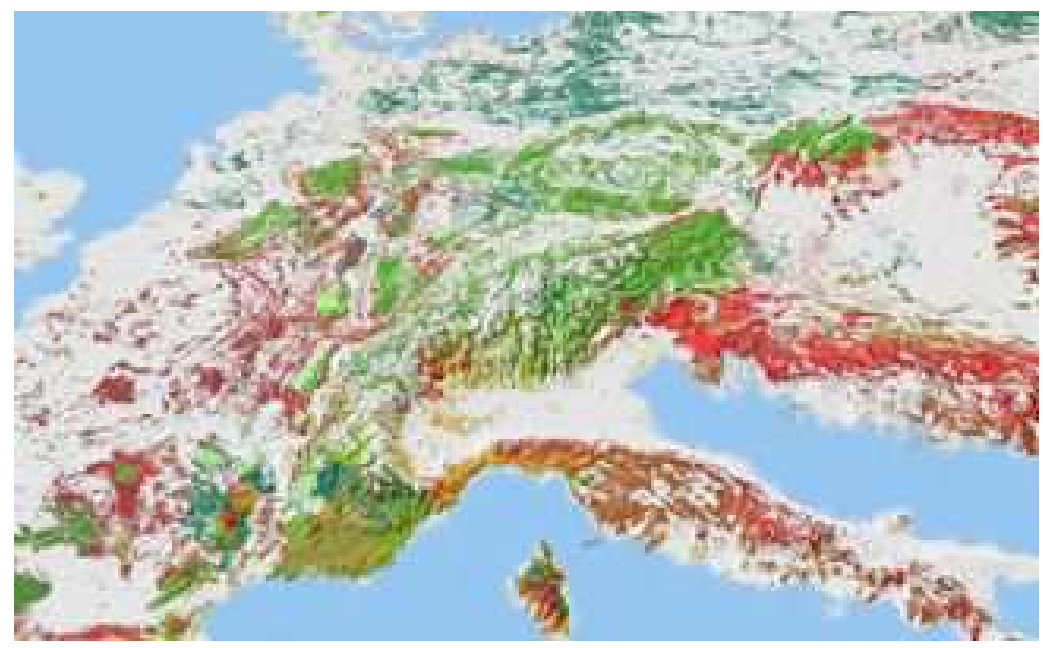

Figure 7. Tree species in Central Europe based on compiled data from National Forest Inventories. Green shades represent coniferous forests, while reddish shades are deciduous forests; [79].

future possible tree species composition to a transparent model realization. The challenge for practical foresters is the evaluation of adaptive management no-regret strategies in order to foster a development where forests can fulfill the expected ecosystem services [78].

A comprehensive niche-modeling exercise led to a prediction of the future tree species distribution for Europe [10]. It is predicted that under now realistic climate change scenarios the share of Norway spruce is going to decline. Spruce will still be the dominant tree in the Alps, but the spruce stands at low elevation are not expected to cope with future climate conditions (Figure 8). Beech (Fagus sylvatica L.) is expected to benefit in the next decades. However, in the long run its habitat is expected to shrink. The tree species that are expected to expand as a consequence of climate change are pines (Pinus sp.) and oaks (Quercus $s p$.). Such a development is highly undesirable for the forestry industry because the most productive tree species will be less abundant whereas tree species with low growth rates or less economic value are on the rise. The benefit of niche models is that practical forestry is already supplied with this information now. Independent scrutiny of the modeling results is given by observations in the southern part of Switzerland, where the proposed species shift according to Figure 8 has been documented in the field [80]. There is still time to develop strategies to deal with climate change effects. Among the emerging fields is the efficient use of the genetic variability of tree species. This strategy is supported by the inherent genetic heterogeneity of many tree species. In particular trees that have a history of migration into different types of ecosystems after the last glaciation have potentially formed several phenotypes that can be efficiently used in forest management [81-83].

The forced migration of a tree species due to climate change is already an extreme manifestation of the change in site conditions. For a substantial amount of time it is likely that trees will adjust their growth rate to the prevailing climate conditions. In Figure 9 the change in productivity is given for different time intervals with the main confounding factor being the pressure from bark beetles (Figure 6). The analysis is based on data from 


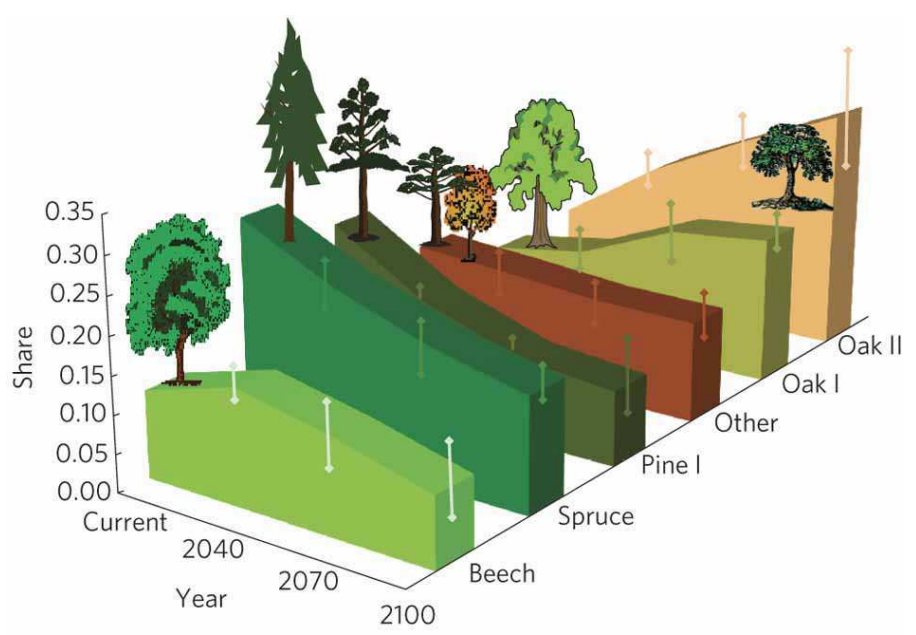

Figure 8. Potential trend of the share of tree species in Europe under the influence of climate change; [10].

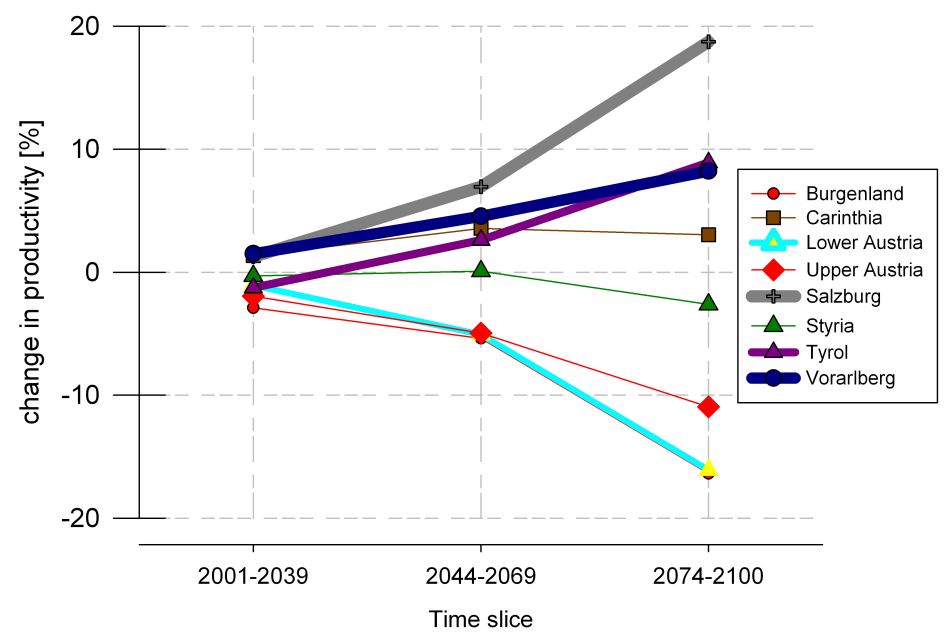

Figure 9. Altered productivity of Austrian forests due to climate change effects, differentiated by provinces.

an earlier experiment [84]. Obviously, climate change does not affect the regions equally. In mountain areas such as Tyrol, Vorarlberg, and Salzburg, the productivity is even going to increase because the main effect of climate change is extension of the growing season. At lower elevations, droughts are going to limit tree growth and the pressure from bark beetles is expected to increase. Therefore, the geographic heterogeneity of landscapes will lead to widely different climate change effects on forest ecosystems. 

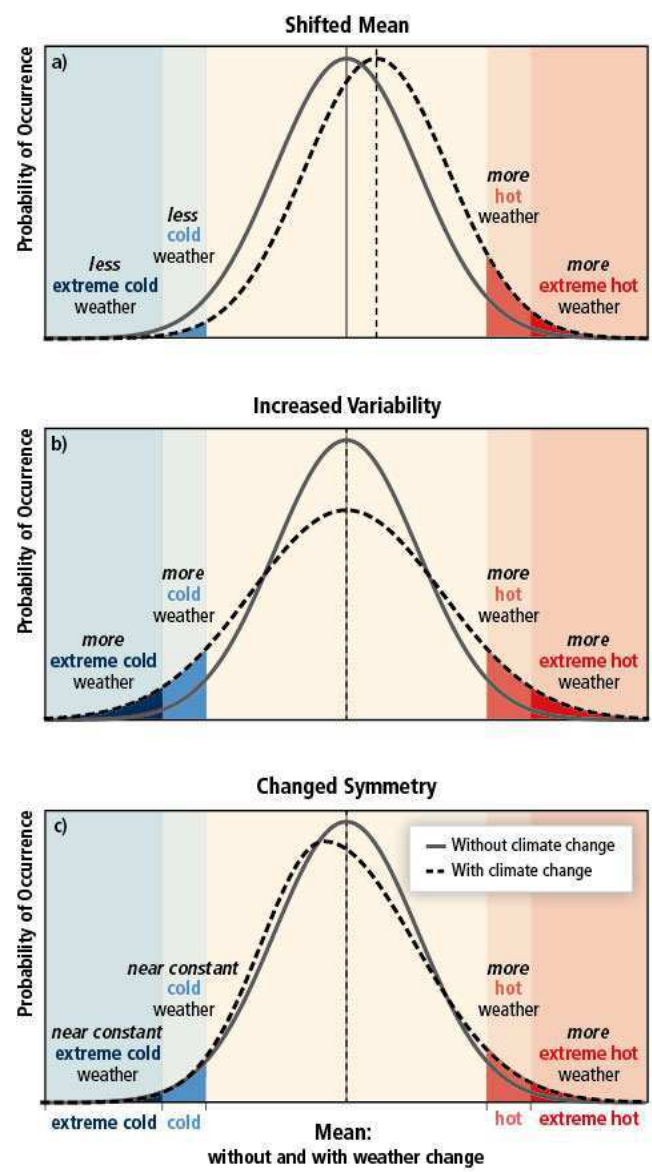

Figure 10. The effect of changes in temperature distribution on extremes. Different changes in temperature distributions between present and future climate and their effects on extreme values of the distributions: (a) effects of a simple shift of the entire distribution toward a warmer climate; (b) effects of an increase in temperature variability with no shift in the mean; (c) effects of an altered shape of the distribution, in this example a change in asymmetry toward the hotter part of the distribution ; [87].

\section{Climate manipulation experiments}

Climate extremes, such as severe drought, heat waves and periods of heavy rainfall, will affect tree growth greatly. Global climate change is expected to increase both the frequency and intensity of climate extremes and there is an urgent need to understand their ecological consequences, in particular with respect to carbon sequestration [85, 86]. The Special Report on Extreme Events by the IPCC distinguishes three forms of the change [87] (Figure 10).

Field experiments are essential for the assessment of ecosystem responses to changing conditions, especially when the complexity of the ecosystems does not allow the deduction of results based on existing knowledge. A challenge in climate change manipulation 

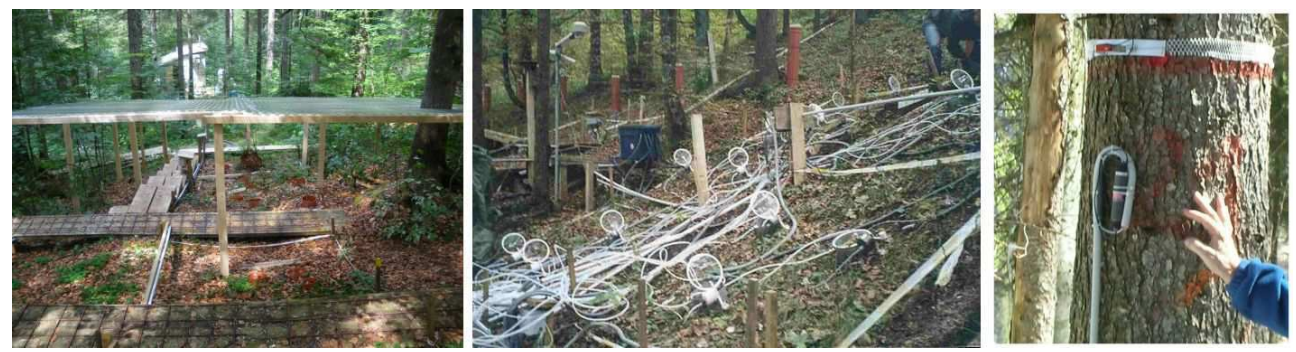

Figure 11. Elements of climate manipulation experiments. Roofs under the tree canopy enable the creation of artificial drought conditions (left), automatic chambers allows the continuous measurement of greenhouse-gas emissions from soils (center), stem diameter growth is a common response variable for the quantification of climate change effects (right).

experiments in forests is their size and longevity. For the assessment of soil processes under conceivable warmer conditions, soil warming experiments have been set up in different forest ecosystems [88-91] (Figure 11).

Another avenue of climate change experiments is the exposure of trees to elevated concentrations of $\mathrm{CO}^{2}$. Several Free-Air-Carbon dioxide-Enrichment (FACE) experiments have been conducted with young and fast-growing trees [92, 93]. Maximum stimulation of tree growth occurred at concentrations up to $560 \mathrm{ppm}$ unless other limiting factors such as water shortage and insufficient nutrient supply set in. For the long-term $C$ sequestration potential of forest ecosystems the FACE experiments are not entirely relevant because the response to elevated $\mathrm{CO}_{2}$ is probably transient [94].

A challenge is setting up experiments with a sufficient duration. Funding schemes of scientific experiments often favor short-duration experiments whereas long-term experiments in ecology are often burdened with insufficient funding [30, 95]. Among the climate manipulation experiments the investigation of droughts has been quite successful and is widely applied. One reason is that the installation of roofs covering experimental plots is rather simple (Figure 11). The technique is already long known and has been used in acid rain research since the 1980s [96].

Much more difficult is the assessment of other extreme events in climate manipulation experiments. Early and late frost events are difficult to create under field conditions. A partial remedy is the formation of scientific networks such as CLIMMANI (http.//www.climmani. org) that bring together key researchers within climate change experiments to build coherent interdisciplinary databases. Such climate manipulation experiments can be combined with long-term ecological research installations [97].

\section{Acknowledgements}

This chapter is an outcome of several projects, such as the MANFRED Project ("Management strategies to adapt Alpine Space forests to climate change risks projects" (Interreg Alpine Space Programme), Ecosoc Cuvée, sponsored by the Austrian Academy of Sciences, and COST 639. 


\section{Author details}

Robert Jandl, Andreas Schindlbacher

Forest Research Center (BFW), Vienna, Austria

\section{References}

[1] FAO. Global Forest Resources Assessment 2010 - Main report, volume 163 of FAO Forestry Paper. FAO, Rome, 2010.

[2] P Kempeneers, F Sedano, L Seebach, P Strobl, and J San-Miguel-Ayanz. Data fusion of different spatial resolution remote sensing images applied to forest-type mapping. IEEE Transactions on Geoscience and Remote Sensing, 49(12):4977-4986, 2011.

[3] R Päivinen, M Lehikoinen, A Schuck, T Häme, S Väätäinen, P Kennedy, and S Folving. Combining Earth Observation Data and Forest Statistics, volume 14 of EFI Research Report. European Forest Institute, Joint Research Centre - European Commission, 2001.

[4] A Schuck, J Van Brusselen, R Päivinen, T Häme, P Kennedy, and S Folving. Compilation of a calibrated European forest map derived from NOAA-AVHRR data., volume 13 of EFI Internal Report. European Forest Institute, 2002.

[5] Wolfgang Russ. Mehr Wald in Österreich. BFW-Praxisinformation, 24:3-5, 2011.

[6] IGBP-TC-WG. The terrestrial carbon cycle: implications for the kyoto protocol. Science, 280:1393-1394, 1998.

[7] IPCC. 2006 IPCC Guidelines for National Greenhouse Gas Inventories - Agriculture, Forestry and Other Land Use, volume 4. National Greenhouse Gas Inventories Programme IGES, Japan, Japan, 2006.

[8] Erich Tasser, Janette Walde, Ulrike Tappeiner, Alexandra Teutsch, and Werner Noggler. Land-use changes and natural reforestation in the eastern central Alps. Agriculture, Ecosystems and Environment, 118:115-129, 2007.

[9] Ulrike Tappeiner, Erich Tasser, Georg Leitinger, Alexander Cernusca, and Gottfried Tappeiner. Effects of historical and likely future scenarios of land use on above- and belowground vegetation carbon stocks of an alpine valley. Ecosystems, 11:1383-1400, 2008.

[10] Marc Hanewinkel, Dominik A. Cullmann, Mart-Jan Schelhaas, Gert-Jan Nabuurs, and Niklaus E. Zimmermann. Climate change may cause severe loss in the economic value of European forest land. Nature Climate Change, 3:203-207, 2012.

[11] Niklaus E. Zimmermann, Robert Jandl, Mark Hanewinkel, Georges Kunstler, Christian Kölling, Patrizia Gasparini, Andrej Breznikar, Eliane S. Meier, Signe Normand, Ulrich Ulmer, Thomas Gschwandtner, Holger Veit, Maria Naumann, Wolfgang Falk, Karl Mellert, Maria Rizzo, Mitja Skudnik, and Achilleas Psomas. Potential future ranges of tree species in the Alps, chapter 4. InTech, 2013. 
[12] Daniel P. Bebber, Mark A. T. Ramotowski, and Sarah J. Gurr. Crop pests and pathogens move polewards in a warming world. Nature Climate Change, 2013.

[13] Holger Griess, Holger Veit, and Ralf Petercord. Risk assessment for biotic pests under prospective climate conditions, chapter 5. InTech, 2013.

[14] M. Jonášová, E. Vávrová, and P. Cudlín. Western Carpathian mountain spruce forest after a windthrow: Natural regeneration in cleared and uncleared areas. Forest Ecology and Management, 259(6):1127 - 1134, 2010.

[15] W. A. Kurz, C. C. Dymond, G. Stinson, G. J. Rampley, E. T. Neilson, A. L. Carroll, T. Ebata, and L. Safranyik. Mountain pine beetle and forest carbon feedback to climate change. Nature, 452:987-990, 2008.

[16] Anders Lindroth, Fredrik Lagergren, Achim Grelle, Leif Klemedtsson, Ola Langvalls, Per Weslien, and Janno Tuulik. Storm can cause a Europe-wide reduction in forest carbon sink. Global Change Biology, 15:346-355, 2009.

[17] Craig D. Allen, Alison K. Macalady, Haroun Chenchouni, Dominique Bachelet, Nate McDowell, Michel Vennetier, Thomas Kitzberger, Andreas Rigling, David D. Breshears, E.H. (Ted) Hogg, Patrick Gonzalez, Rod Fensham, Jorge Castro Zhen Zhang, Natalia Demidova, Jong-Hwan Limp, Gillian Allard, Steven W. Running, Akkin Semerci, and Neil Cobb. A global overview of drought and heat-induced tree mortality reveals emerging climate change risks for forests. Forest Ecology and Management, 250:660-684, 2010.

[18] Peter Brang, Marc Hanewinkel, Robert Jandl, Andrej Breznikar, and Bernhard Maier. Managing Alpine Forests in a Changing Climate, chapter 20. InTech, 2013.

[19] Robert Jandl and Martin Price. Climate change. In Martin F Price, Georg Gratzer, Lalisa Alemayehu Duguma, Thomas Kohler, Daniel Maselli, and Rosalaura Romeo, editors, Mountain Forests in a Changing World - Realizing Values, addressing challenges, chapter 8, pages 62-63. FAO, Rome, 2011.

[20] Zoltan Somogyi, Ciara Hayes, Alexandra Freudenschuss, and Rainer Baritz. Reporting requirements for the estimation of greenhouse gas emissions and removals of soils in the land use sector, chapter 9, pages 219-238. Wiley-Blackwell, 2011.

[21] Z. Somogyi, A. Bidló, I. Csiha, and G. Illé. Country-level carbon balance of forest soils: a country-specific model based on case studies in Hungary. European Journal of Forest Research, 2013.

[22] Robert Jandl and Mats Olsson. Introduction to carbon in sensitive European ecosystems: from science to land management, chapter 1, pages 1-12. Wiley-Blackwell, 2011.

[23] Erkki Tomppo, Thomas Gschwantner, Mark Lawrence, and Ronald E McRoberts, editors. National Forest Inventories - Pathways for common reporting. Springer, Heidelberg, 2010. 
[24] I. Brunner, M. R. Bakke, R. G. Björk, Y. Hirano, M. Lukac, X. Aranda, I. Børja, T. D. Eldhuset, H. S. Helmisaari, C. Jourdan, B. Konôpka, B. C. López, C. Miguel Pérez, H. Persson, and I. Ostonen. Fine-root turnover rates of European forests revisited: an analysis of data from sequential coring and ingrowth cores. Plant and Soil, 362:357-372, 2013.

[25] Bohdan Konôpka, Jozef Pajtík, Vladimir Šebeň, and Martin Lukac. Belowground biomass functions and expansion factors in high elevation Norway spruce. Forestry, 2010.

[26] Klaus Lorenz. Carbon dynamics and pools in major forest biomes of the world. In Klaus Lorenz and Rattan Lal, editors, Carbon Sequestration in Forest Ecosystems, chapter 4. Springer, New York, 2010.

[27] Dimitris Zianis, Petteri Mukkonen, Raisa Mäkipää, and Maurizio Mencuccini. Biomass and stem volume equations for tree species in Europe. Silva Fennica Monographs, 4:63p, 2005.

[28] K. E. Clemmensen, A. Bahr, O. Ovaskainen, A. Dahlberg, A. Ekblad, H. Wallander, J. Stenlid, R. D. Finlay, D. A. Wardle, and B. D. Lindahl. Roots and associated fungi drive long-term carbon sequestration in boreal forest. Science, 339(6127):1615-1618, 2013.

[29] R. Hiederer and T. Durrant. Evaluation of biosoil demonstration project - preliminary data analysis. Technical Report EUR 24258 EN, Office for Official Publications of the European Communities, Luxembourg, 2010.

[30] Robert Jandl, Mirco Rodeghiero, Cristina Martinez, M. Francesca Cotrufo, Francesca Bampa, Bas van Wesemael, Robert B Harrison, Iraê Amaral Guerrini, Daniel deB Richter Jr., Lindsey Rustad, Klaus Lorenz, Abad Chabbi, and Franco Miglietta. Current status, uncertainty and future needs in soil organic carbon monitoring. The Science of the Total Environment, 468-469:376-383, 2014.

[31] René Schils, Peter Kuikman, Jari Liski, Marcel van Oijen, Pete Smith, Jim Webb, Jukka Alm, Zoltan Somogyi, Jan van den Akker, Mike Billett, Bridget Emmett, Chris Evans, Marcus Lindner, Taru Palosuo, Patricia Bellamy, Jukka Alm, Robert Jandl, and Ronald Hiederer. Review of existing information on the interrelations between soil and climate change. Alterra, Wageningen, 2008.

[32] Ivan A. Janssens, Annette Freibauer, Philippe Ciais, Pete Smith, Gert-Jan Nabuurs, Gerd Folberth, Bernhard Schlamadinger, Ronald W. A. Hutjes, Reinhart Ceulemans, E.-Detlef Schulze, Riccardo Valentini, and A. Johannes Dolman. Europe's terrestrial biosphere absorbs 7 to $12 \%$ of European anthropogenic $\mathrm{CO}_{2}$ emissions. Science, 300:1538-1542, 2003.

[33] Glen P. Peters, Gregg Marland, Corinne Le Quéré, Thomas Boden, Josep G. Canadell, and Michael R. Raupach. Rapid growth in $\mathrm{CO}_{2}$ emissions after the 2008-2009 global financial crisis. Nature Climate Change, 2:2-4, 2011. 
[34] Corinne Le Quéré, Michael R. Raupach, Josep G. Canadell, Gregg Marland, Laurent Bopp, Philippe Ciais, Thomas J. Conway, Scott C. Doney, Richard A. Feely, Pru Foster, Pierre Friedlingstein, Kevin Gurney, Richard A. Houghton, Joanna I. House, Chris Huntingford, Peter E. Levy, Mark R. Lomas, Joseph Majkut, Nicolas Metzl, Jean P. Ometto, Glen P. Peters, I. Colin Prentice, James T. Randerson, Steven W. Running, Jorge L. Sarmiento, Ute Schuster, Stephen Sitch, Taro Takahashi, Nicolas Viovy, Guido R. van der Werf, and F. Ian Woodward. Trends in the sources and sinks of carbon dioxide. Nature Geoscience, 2:831-836, 2009.

[35] C. Le Quéré, R. Andres, T. Boden, T. Conway, R. Houghton, J. House, G. Marland, G. Peters, G. van der Werf, A. Ahlström, R. Andrew, L. Bopp, J. Canadell, P. Ciais, S. Doney, C. Enright, P. Friedlingstein, C. Huntingford, A. Jain, C. Jourdain, E. Kato, R. Keeling, K. Klein Goldewijk, S. Levis, P. Levy, M. Lomas, B. Poulter, M. Raupach, J. Schwinger, S. Sitch, B. Stocker, N. Viovy, S. Zaehle, and N. Zeng. The global carbon budget 1959-2011. Earth System Science Data Discussions, 5:1107-1157, 2012.

[36] Yude Pan, Richard A. Birdsey, Jingyun Fang, Richard Houghton, Pekka E. Kauppi, Werner A. Kurz, Oliver L. Phillips, Anatoly Shvidenko, Simon L. Lewis, Josep G. Canadell, Philippe Ciais, Robert B. Jackson, Stephen Pacala, A. David McGuire, Shilong Piao, Aapo Rautiainen, Stephen Sitch, and Daniel Hayes. A large and persistent carbon sink in the world's forests. Science, 333:988-993, 2011.

[37] Robert Jandl. Forests: The carbon conundrum. IUFRO Spotlight, 4:1, 2012.

[38] Peter M Cox, Richard A Betts, Chris D Jones, Steven A Spall, and Ian J Totterdell. Acceleration of global warming due to carbon-cycle feedbacks in a coupled climate model. Nature, 408:184-187, 2000.

[39] S. Luyssaert, P. Ciais, S. L. Piao, E.-D. Schulze, M. Jung, S. Zaehle, M. J. Schelhaas, M. Reichstein, G. Churkina, D. Papale, G. Abril, C. Beer, J. Grace, D. Loustau, G. Matteucci, F. Magnani, G. J. Nabuurs, H. Verbeeck, M. Sulkava, G. R. Van Der Werf, I. A. Janssens, and members of the CARBOEUROPE-IP SYNTHESIS TEAM. The European carbon balance. Part 3: forests. Global Change Biology, 16(5):1429-1450, 2010.

[40] Gert-Jan Nabuurs, Marcus Lindner, Pieter J. Verkerk, Katja Gunia, Paola Deda, Roman Michalak, and Giacomo Grassi. First signs of carbon sink saturation in European forest biomass. Nature Climate Change, advance online publication, 2013.

[41] Nicole Mandl. Annual European Union greenhouse gas inventory 1990-2011 and inventory report 2013. Submission to the UNFCCC Secretariat. Technical Report 8, European Environment Agency, Copenhagen, May 272013.

[42] Michael Anderl, Alexandra Freudenschuss, Angela Friedrich, Simone Haider, Heide Jobstmann, Traute Köther, Martin Kriech, Verena Kuschel, Christoph Lampert, Katja Pazdernik, Stephan Poupa, Maria Purzner, Melanie Sporer, Barbara Schodl, Gudrun Stranner, Elisabeth Schwaiger, Katrin Seuss, Peter Weiss, Manuela Wieser, and Gerhard Zethner Andreas Zechmeister. Austrias National Inventory Report 2012. Submission under the United Nations Framework Convention on Climate Change and the Kyoto Protocol. Technical Report REP-0381, Umweltbundesamt, Vienna, 2012. 
[43] Gerhard Glatzel. Historic land use and its possible implications to recently accelerated tree growth in central Europe. In Timo Karjalainen, Heinrich Spiecker, and Olivier Laroussinie, editors, Causes and consequences of accelerating tree growth in Europe, volume 29 of EFI Proceedings, pages 65-74. EFI, Joensuu, 1999.

[44] Jed O. Kaplan, Kristen M. Krumhardt, and Niklaus Zimmermann. The prehistoric and preindustrial deforestation of Europe. Quaternary Science Reviews, 28(27-28):3016 - 3034, 2009.

[45] Robert Jandl, Andreas Schindlbacher, Silvio Schüler, and Dieter Stöhr. Wald- und Waldgrenzenforschung in Obergurgl - Vergangenheit und Zukunft, volume 2 of Alpine Forschungsstelle Obergurgl, chapter 5, pages 125-145. Innsbruck University Press, 2012.

[46] Hannes Mayer. Gebirgswaldbau - Schutzwaldpflege. Gustav Fischer Verlag, Stuttgart, 1976.

[47] Garrett Hardin. The tragedy of the commons. Science, 162:1243-1248, 1968.

[48] C Hegg, BW McArdell, and A Badoux. One hundred years of mountain hydrology in Switzerland by the WSL. Hydrological Processes, 20:371-376, 2006.

[49] Walter Moser and Jeannie Peterson. Limits to Obergurgl's growth. Ambio, 10(2-3):68-72, 1981.

[50] Dieter Stöhr. Gegen die Destabilisierung der Bergwälder. In Ecological and economic benefits of mountain forests, Innsbruck, September 15-18 2002.

[51] T. Eglin, P. Ciais, S. L. Piao, P. Barre, V. Bellassen, P. Cadule, C. Chenu, T. Gasser, C. Koven, M. Reichstein, and P. Smith. Historical and future perspectives of global soil carbon response to climate and land-use changes. Tellus B, 62(5):700-718, 2010.

[52] Christopher Poeplau, Axel Don, Lars Vesterdal, Jens Leifeld, Bas Van Wesemael, Jens Schumacher, and Andreas Gensior. Temporal dynamics of soil organic carbon after land-use change in the temperate zone carbon response functions as a model approach. Global Change Biology, 17(7):2415-2427, 2011.

[53] Angelika Thuille and Ernst-Detlef Schulze. Carbon dynamics in successional and afforested spruce stands in thuringia and the alps. Global Change Biology, 12:325-342, 2006.

[54] Richard H. Moss, Jae A. Edmonds, Kathy A. Hibbard, Martin R. Manning, Steven K. Rose, Detlef P. van Vuuren, Timothy R. Carter, Seita Emori, Mikiko Kainuma, Tom Kram, Gerald A. Meehl, John F. B. Mitchell, Nebojsa Nakicenovic, Keywan Riahi, Steven J. Smith, Ronald J. Stouffer, Allison M. Thomson, John P. Weyant, and Thomas J. Wilbanks. The next generation of scenarios for climate change research and assessment. Nature, 463:747-756, 2010.

[55] Retto Knutti and Jan Sedláček. Robustness and uncertainties in the new CMIP5 climate model projections. Nature Climate Change, 2012. 
[56] Ernst Gebetsroither and Johann Züger. Drought hazard estimations according to climate change in the Alpine area, chapter 11. Intech, 2013.

[57] Justin Sheffield, Eric F.Wood, and Michael L. Roderick. Little change in global drought over the past 60 years. Nature, 491:435-438, 2012.

[58] Brendan Choat, Steven Jansen, Tim J. Brodribb, Hervé Cochard, Sylvain Delzon, Radika Bhaskar, Sandra J. Bucci, Taylor S. Feild, Sean M. Gleason, Uwe G. Hacke, Anna L. Jacobsen, Frederic Lens, Hafiz Maherali, Jordi Martínez-Vilalta, Stefan Mayr, Maurizio Mencuccini, Patrick J. Mitchell, Andrea Nardini, Jarmila Pittermann, R. Brandon Pratt, John S. Sperry, Mark Westoby, Ian J. Wright, and Amy E. Zanne. Global convergence in the vulnerability of forests to drought. Nature, 491:751-756, 2012.

[59] Simon L. Lewis, Paulo M. Brando, Oliver L. Phillips, Geertje M. F. van der Heijden, and Daniel Nepstad. The 2010 amazon drought. Science, 331(6017):554, 2011.

[60] Giacomo Certini. Effects of fire on properties of forest soils: a review. Oecologia, 143:1-10, 2005.

[61] A. L. Westerling, H. G. Hidalgo, D. R. Cayan, and T. W. Swetnam. Warming and earlier spring increase western U.S. forest wildfire activity. Science, 313(5789):940-943, 2006.

[62] Barry Gardiner, Kristina Blennow, Jean-Michel Carnus, Peter Fleischer, Frederik Ingemarson, Guy Landmann, Marcus Lindner, Mariella Marzano, Bruce Nicoll, Christophe Orazio, Jean-Luc Peyron, Marie-Pierre Reviron, Mart-Jan Schelhaas, Andreas Schuck, Michaela Spielmann, and Tilo Usbeck. Destructive Storms in European Forests: Past and Forthcoming Impacts. EFI, Joensuu, 2010.

[63] M. G. Donat, D. Renggli, S. Wild, L. V. Alexander, G. C. Leckebusch, and U. Ulbrich. Reanalysis suggests long-term upward trends in European storminess since 1871. Geophysical Research Letters, 38:L14703, 2011.

[64] U. Ulbrich, G. C. Leckebusch, and J. G. Pinto. Extra-tropical cyclones in the present and future climate: a review. Theoretical and Applied Climatology, 96:117-131, 2009.

[65] Christian Tomiczek and Ute Hoyer-Tomiczek. Der Asiatische Laubholzbockkäfer (Anoplophora glabripennis) und der Citrusbockkäfer (Anoplophora chinensis) in Europa ein Situationsbericht. Forstschutz Aktuell, 38:2-5, 2007.

[66] Robert Jandl, Silvio Schüler, Andreas Schindlbacher, and Christian Tomiczek. Forests, carbon pool, and timber production. In Rattan Lal, Klaus Lorenz, Reinhard F Hüttl, Bernd Uwe Schneider, and Joachim von Braun, editors, Ecosystem Services and Carbon Sequestration in the Biosphere, chapter 6, pages 101-130. Springer Verlag, Dordrecht, 2013.

[67] Christian Körner. Slow in, rapid out - carbon flux studies and Kyoto targets. Science, 300:1242-1243, 2003.

[68] Virginia H. Dale, Linda A. Joyce, Steve McNulty, Ronald P. Neilson, Matthew P. Ayres, Michael D. Flannigan, Paul J. Hanson, Lloyd C. Irland, Ariel E. Lugo, Chris J. Peterson, 
Daniel Simberloff, Frederick J. Swanson, Brian J. Stocks, and B. Michael Wotton. Climate change and forest disturbances. BioScicence, 51(9):723-734, 2001.

[69] Jerry F. Franklin, Thomas A. Spies, Robert Van Pelt, Andrew B. Carey, Dale A. Thornburgh, Dean Rae Berg, David B. Lindenmayer, Mark E. Harmon, William S. Keeton, David C. Shaw, Ken Bible, and Jiquan Chen. Disturbances and structural development of natural forest ecosystems with silvicultural implications, using Douglas-fir forests as an example. Forest Ecology and Management, 155:399-423, 2002.

[70] Marc Hanewinkel, Johannes Breidenbach, Till Neeff, and Edgar Kublin. Seventy-seven years of natural disturbances in a mountain forest area - the influence of storm, snow, and insect damage analysed with a long-term time series. Canadian Journal of Forest Research, 38(8):2249-2261, 2008.

[71] Rupert Seidl, Paulo M. Fernandes, Teresa F. Fonseca, François Gillet, Anna Maria Jönsson, Katarína Merganicová, Sigrid Netherer, Alexander Arpaci, Jean-Daniel Bontemps, Harald Bugmann, Jose Ramon González-Olabarria, Petra Lasch, Céline Meredieu, Francisco Moreira, Mart-Jan Schelhaas, and Frits Mohren. Modelling natural disturbances in forest ecosystems: a review. Ecological Modelling, 222(4):903 - 924, 2011.

[72] Rupert Seidl, Mart-Jan Schelhaas, and Manfred J Lexer. Unraveling the drivers of intensifying forest disturbance regimes in Europe. Global Change Biology, 17(9):2842-2852, 2011.

[73] Ernst Assmann. Waldertragskunde - Organische Produktion, Struktur, Zuwachs und Ertrag von Waldbeständen. BLV Verlagsgesellschaft, München, 1961.

[74] Hannes Mayer. Wälder des Ostalpenraumes - Standort, Aufbau und waldbauliche Bedeutung der wichtigsten Waldgesellschaften in den Ostalpen samt Vorland. G. Fischer, Stuttgart, 1974.

[75] Xavier Morin and Wilfried Thuiller. Comparing niche- and process-based models to reduce prediction uncertainty in species range shifts under climate change. Ecology, 90(5):1301-1313, 2009.

[76] W. Thuiller, B. Lafourcade, R. Engler, and M.B. Araújo. Biomod - a platform for ensemble forecasting of species distributions. Ecography, 32:369-373, 2009.

[77] Niklaus E. Zimmermann, Nigel G. Yoccoz, Thomas C. Edwards Jr., Eliane S. Meier, Wilfried Thuiller, Antoine Guisan, Dirk R. Schmatz, and Peter B. Pearman. Climatic extremes improve predictions of spatial patterns of tree species. PNAS, 106:19723-19728, 2009.

[78] Kristina Blennow, Johannes Persson, Margarida Tomé, and Marc Hanewinkel. Climate change: Believing and seeing implies adapting. PLoS ONE, 7:e50182, 112012.

[79] D. J. Brus, G. M. Hengeveld, D. J. J. Walvoort, P. W. Goedhart, A. H. Heidema, G. J. Nabuurs, and K. Gunia. Statistical mapping of tree species over europe. European Journal of Forest Research, 131:145-157, 2011. 
[80] Andreas Rigling, Christof Bigler, Britta Eilmann, Elisabeth Feldmeyer-Christe, Urs Gimmi, Christian Ginzler, Ulrich Graf, Philipp Mayer, Giorgio Vacchiano, Pascale Weber, Thomas Wohlgemuth, Roman Zweifel, and Matthias Dobbertin. Driving factors of a vegetation shift from scots pine to pubescent oak in dry alpine forests. Global Change Biology, 19(1):229-240, 2013.

[81] Małgorzata Latałowa and W.O. van der Knaap. Late Quaternary expansion of Norway spruce Picea abies (L.) Karst. in Europe according to pollen data. Quaternary Science Reviews, 25(21-22):2780 - 2805, 2006.

[82] Stefan Kapeller, Manfred J. Lexer, Thomas Geburek, Johann Hiebl, and Silvio Schueler. Intraspecific variation in climate response of norway spruce in the eastern alpine range: Selecting appropriate provenances for future climate. Forest Ecology and Management, 271:46-57, 2012.

[83] T. Wang, A Hamann, Y Yanchuk, GA O'Neill, and SN Aiken. Use of response functions in selecting lodgepole pine populations for future climates. Global Change Biology, 12:2404-2416, 2006.

[84] Rupert Seidl, Mart-Jan Schelhaas, Marcus Lindner, and ManfredJ. Lexer. Modelling bark beetle disturbances in a large scale forest scenario model to assess climate change impacts and evaluate adaptive management strategies. Regional Environmental Change, 9(2):101-119, 2009.

[85] Markus Reichstein, Michael Bahn, Philippe Ciais, Dorothea Frank, Miguel D. Mahecha, Sonia I. Seneviratne, Jakob Zscheischler, Christian Beer, Nina Buchmann, David C. Frank, Dario Papale, Anja Rammig, Pete Smith, Kirsten Thonicke, Marijn van der Velde, Sara Vicca, ArianeWalz, and Martin Wattenbach. Climate extremes and the carbon cycle. Nature, 500:287-295, 2013.

[86] Melinda D. Smith. The ecological role of climate extremes: current understanding and future prospects. Journal of Ecology, 99(3):651-655, 2011.

[87] IPCC. Managing the Risks of Extreme Events and Disasters to Advance Climate Change Adaptation. A Special Report of Working Groups I and II of the Intergovernmental Panel on Climate Change. Cambridge University Press, Cambridge, UK, and New York, NY, USA, 2012.

[88] Frank Hagedorn, Melissa Martin, Christian Rixen, Silvan Rusch, Peter Bebi, Alois Zürcher, Rolf T. W. Siegwolf, Sonja Wipf, Christophe Escape, Jacques Roy, and Stephan Hättenschwiler. Short-term responses of ecosystem carbon fluxes to experimental soil warming at the Swiss alpine treeline. Biogeochemistry, 97:7-19, 2010.

[89] Jerry M. Melillo, Sarah Butler, Jennifer Johnson, Jacqueline Mohan, Paul Steudler, Heidi Lux, Elizabeth Burrows, Francis Bowles, Rose Smith, Lindsay Scott, Chelsea Vario, Troy Hill, Andrew Burton, Yu-Mei Zhouj, and Jim Tang. Soil warming, carbon-nitrogen interactions, and forest carbon budgets. PNAS, 108(23):9508-9512, 2011. 
[90] Andreas Schindlbacher, Sophie Zechmeister-Boltenstern, Barbara Kitzler, and Robert Jandl. Experimental forest soil warming: response of autotrophic and heterotrophic soil respiration to a short-term $10^{\circ} \mathrm{C}$ temperature rise. Plant and Soil, 303:323-330, 2008.

[91] A. Schindlbacher, S. Wunderlich, W. Borken, B. Kitzler, S. Zechmeister-Boltenstern, and R. Jandl. Soil respiration under climate change: Prolonged summer drought offsets soil warming effects. Global Change Biology, 18:2270-2279, 2012.

[92] Martin Lukac, Carlo Calfapietra, and Douglas L Godbold. Production, turnover and mycorrhizal colonization of root systems of three populus species grown under elevated $\mathrm{CO}_{2}$ (POPFACE). Global Change Biology, 9:838-848, 2003.

[93] Richard J. Norby and Donald R. Zak. Ecological lessons from free-air $\mathrm{CO}_{2}$ enrichment (face) experiments. Annual Review of Ecology, Evolution, and Systematics, 42(1):181-203, 2011.

[94] Christian Körner, Roman Asshoff, Olivier Bignucolo, Stephan Hättenschwiler, Sonja G. Keel, Susanna Peláez-Riedl, Steve Pepin, Rolf T. W. Siegwolf, and Gerhard Zotz. Carbon flux and growth in mature deciduous forest trees exposed to elevated $\mathrm{CO}_{2}$. Science, 309:1360-1363, 2005.

[95] Robert Jandl, Stefan Smidt, Andreas Schindlbacher, Michael Englisch, Sophie Zechmeister-Boltenstern, Christian Mikovits, Philipp Schöftner, Friederike Strebl, and Gabriele Fuchs. The carbon and nitrogen biogeochemistry of a montane Norway spruce (Picea abies (L.) Karst.) forest: a synthesis of long-term research. Plant Ecology \& Diversity, 5(1):105-114, 2012.

[96] N.P. Lamersdorf, C. Beier, K. Blanck, M. Bredemeier, T. Cummins, E.P. Farrell, K. Kreutzer, L. Rasmussen, M. Ryan, W. Weis, and X.-J. Xu. Effect of drought experiments using roof installations on acidification/nitrification of soils. Forest Ecology and Management, 101:95-109, 1998.

[97] Daniel D Richter Jr., Michael Hofmockel, Mac A. Callaham jr., David S. Powlson, and Pete Smith. Long-term soil experiments: Keys to managing Earth's rapidly changing ecosystems. Soil Science Society America Journal, 71(2):266-279, 2007. 
